\title{
$\mathrm{Ni}$ 基超合金単結晶の高温強度に及ぼす 塑性異方性の影響
}

\author{
筧幸次 \\ 東京都立大学大学院工学研究科
}

J. Japan Inst. Metals, Vol. 63, No. 3 (1999), pp. 326-332

\section{Influence of Plastic Anisotropy on High Temperature Strength of Single Crystals of a Nickel-Base Superalloy}

Koji Kakehi

\begin{abstract}
Department of Mechanical Engineering, Graduate School of Engineering, Tokyo Metropolitan University, Hachioji 192-0397
\end{abstract}

The effects of crystallographic orientation on the tensile and creep strength of the notched specimens of single crystals of a nickel-base superalloy have been examined at $900^{\circ} \mathrm{C}$. The different plastic anisotropy among four kinds of the notched specimens was interrupted by changing the arrangement of slip systems. The tensile and creep strength of the notched specimens were affected by the crystallographic orientations not only in the tensile direction but also in the thickness direction. At $700^{\circ} \mathrm{C}$, assuming that $\{111\}\langle\overline{1} 01\rangle$ type slip systems were operated in the tensile tests and the $\{111\}\langle 112\rangle$ type slip systems in the creep tests, the test results could be explained very well. In this study, at $900^{\circ} \mathrm{C}$, the results of the tensile tests and creep tests were discussed on the assumption of that $\{111\}\langle\overline{1} 01\rangle$ type slip (octahedral slip) systems were in operation. The test results could not be explained just by the operation of the $\{111\}\langle\overline{1} 01\rangle$ slip system. Therefore, it was assumed that the operation of $\{010\}\langle 101\rangle$ type slip (cube slip) systems and diffusion-controlled deformation mechanisms should be taken into account at this temperature.

(Received May 27, 1998; In Final Form September 2, 1998)

Keywords: single crystals, crystallographic orientation, a nickel-base superalloy, plastic anisotropy, tensile strength, creep strength, arrangement of slip systems

\section{I．緒言}

ガスタービン動翼として，航空機で既に実用化されている $\mathrm{Ni}$ 基超合金単結晶を，発電用タービンへ適用することが検 討されている.ガスタービンの動，静翼では，起動，停止に 伴ら温度变動と周囲の拘束により繰り返し熱応力が生じここ れが部材損傷の主要因となっている，単結晶村の場合，損傷 はすべり系の活動々密接な関係があることから，単結晶材の 寿命は，すべり系の拘束条件の影響を受けることが考光られ る. 単結晶は本質的に顕著な塑性異方性をるつ材料である. 単結晶の塑性異方性は，板状試験片に执いて，応力負荷方向 および板厚方向の結晶方位によって定まるすべり系の配置に よって決まる。こうしたことから，板状試験片の応力負荷力 向执よび板厚方向の結晶方位の組合好が単結晶材料の切欠き 強度に大さな影響を及ぼすと考えられる，乙たがって，応力 負荷方向々板厚方向の結晶方位をどの様に選択するかが，単 結晶材を有効利用するために垁用上重要である(1)(2)。強度の ピーク温度以下の引張試験では $\{111\}\langle 101\rangle$ すべり系(3) の活
動を，また，クリープ試験では\{111\}〈112〉すべり系(4)の活 動を考えることにより，塑性異方性の影響について合理的に 説明できた(5)。本研究では, 強度のピーク温度を越えた高温 域 $\left(900^{\circ} \mathrm{C}\right)$ 飞打いて，4 種類の方位関係をつ薄板切欠き試 験片を用いて, Ni 基超合金単結晶材の高温引張強度および クリープ強度に及ぼす塑性異方性の影響について検討した。

\section{II．すべり系の配置と塑性異方性}

切欠さ材の強度と延性は, 応力状態に強く依存し, 平面応 力状態と平面昰状態とでは大幅に異なる、単軸引張を受ける 多結晶切欠き材の切久き先端領域での变形様式を大別すると Fig. 1 に示すよ5に，平面応才状態で面外すべりからな る $45^{\circ}$ 世九断型の変形, 平面ひずみ状態では面内すべりから なる Hinge type の変形が起こることが Hahn らにより報告 されている(6). Hahnらの結果は, 単に板厚が変化すること による応力状態の変化に起因するるのである。一方, 単結晶 材に沶いては，すべり系の配置を変克ることによって塑性異 万性が著しく変化するため, 上記変形様式の変化が顕著に生 


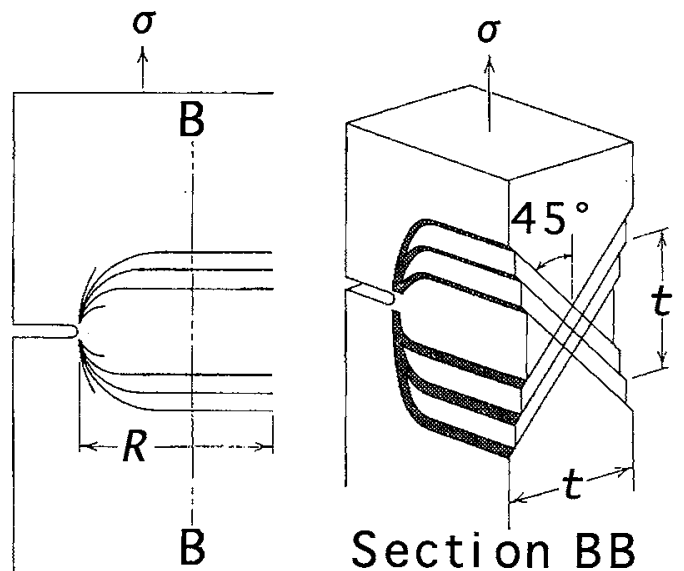

(a) $45^{\circ}$ Shear - Type

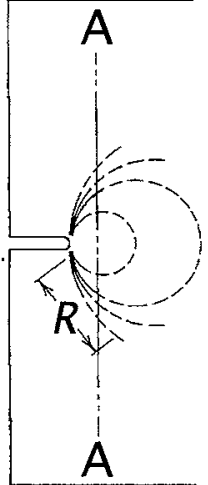

(b) Hinge

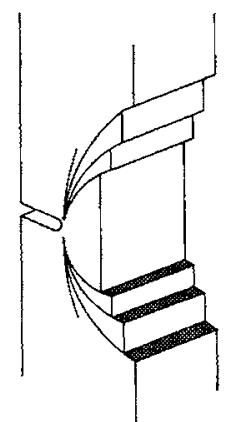

Section $A A$

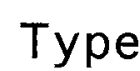

Fig. 1 Schematic drawing of two types of deformation associated with (a) the $45^{\circ}$-shear-type and (b) the hinge-type plastic zone.

じることが考えられる.したがって, 単結晶材のように, 顕 著な塑性異方性をもつ材料では，応力状態のみならず塑性異 方性も大さな影響を及佂し，両者の組合せ方によって切欠き 強度と延性が大幅に変化することは容易に予想できる．本章 では単結晶材の結晶方位を適宜選ぶことによって 4 種類の

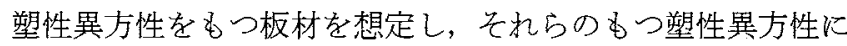
ついて詳細に検討した。

Fig. 2 に，試験片座標系 $\left(X_{1}, X_{2}, X_{3}\right)$ とすべり系座標系 $\left(x_{1}, x_{2}, x_{3}\right)$ 示す.

$\sigma_{22}$ K加㝋て， $\sigma_{11}$ と $\sigma_{33}$ が同時飞作用する多軸応力状態 にあって，各す心゙り系に作用する分解せ九断応力，岕よびひ ずみの值を Table $1^{(1)} に$ 示す。 $g_{\mathrm{t}}, g_{\mathrm{w}}$ は，それぞれ，板厚， 板幅方向に発生するせん断ひずみ(shear distortion)である.

な抏，以下の説明では，単純な 1 軸引張変形に扎いて板 厚を減少させるすべり系を Tグループ，板幅を減少させる すベり系のグループをW グループと呼ぶ.

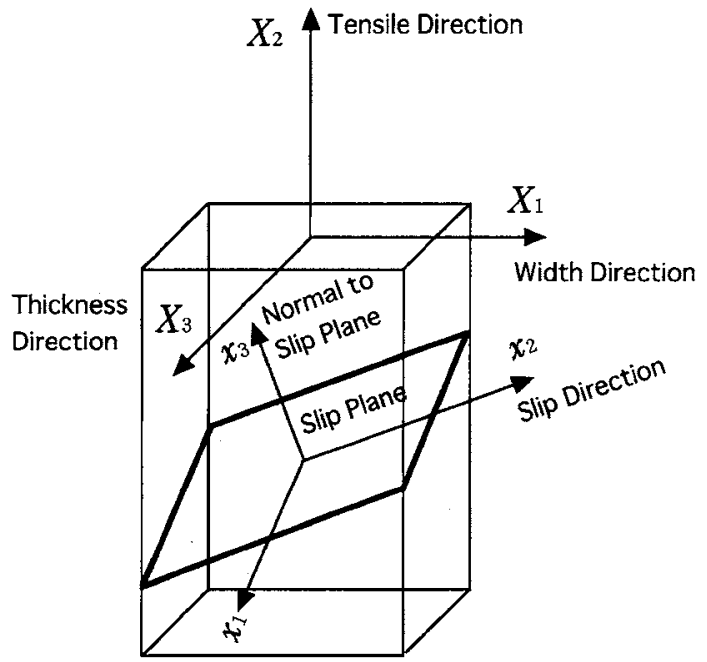

Fig. 2 The test-piece coordinate system $X_{i}(i=1,2,3)$ are taken along the width, the tensile and the thickness directions of the specimen, respectively. The axes of the slip-system coordinate system $x_{j}(j=1,2,3)$ are taken for each principal slip system.

\section{1. $\{111\}\langle\overline{1} 01\rangle$ 型すべり系が活動するとき}

$\{111\}\langle\overline{1} 01\rangle$ 型すべり系が活動するときの切欠き強度に及 ぼす因子としては，次の3つが考学られる。

\section{（1）切欠き拘束効果}

Fig. 3 K，4種類の塑性異方性をもつ板材の結晶方位と活 動するすべり系の幾何学的関係を示す．図示した $\{111\}$ 〈101〉型すべり系は，最す大きい分解せん断応力が作用する すべり系である。このすべり系を主すべり系(Principal Slip System) と呼び，この主すべり系の活動のみを考光る。平滑 試験片K， 1 軸引張応力 $\sigma_{22}$ のみが作用するとき，不安定す ベりが生じないと仮定すれば，すべての主すべり系には，等 しい大ささの分解せん断応力 $\sigma_{22} / \sqrt{6}$ が作用する。

4 種類の塑性異方性をるつ板材の塑性異方性について述べ る。

\section{A 方位 :}

平滑試験片に 1 軸引張応力 $\sigma_{22}$ が作用するとき，4つの主 すべり系には，同じ大きさの分解せん断応力とせん断ひずみ が発生する. 横方向の塑性ひずみとしては愿さ方向の塑性ひ ずみ $\varepsilon_{33}$ のみが発生し，幅方向の塑性ひずみ $\varepsilon_{11}$ は 0 である. したがって，A方位の塑性異方性は，r=0と表すことがで きる，Table 1 K示すよら飞，多軸応力状態に物いては，主 すべり系化作用する分解せ九断応力は板厚方向の引張応力 $\sigma_{33}$ のみによって低下し，幅力向の応力 $\sigma_{11}$ の影響は受けな

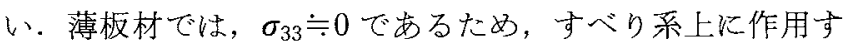
るせん断応力 $\tau$ は低下せず，切欠き強さは低いであるら．

B 方位 :

$\mathrm{B}$ 方位には 8 つの主すべり系がある. 1 軸引張応力 $\sigma_{22}$ が 作用すると，8つの主すべり系には等しい大きさの分解せん 断応力が作用する．各すべり系性等量すべり，r=1である. 
Table 1 Resolved shear stress on each slip system $\tau$, plastic distortion $\varepsilon_{i j}$, Lankford's $r$ value, and combination for the Lomer-Cottrell barrier. $g_{\mathrm{t}}$ and $g_{\mathrm{w}}$ are the total distortion of the $\mathrm{T}$ - and $\mathrm{W}$-Group slip systems, respectively.

\begin{tabular}{|c|c|c|c|c|c|c|}
\hline $\begin{array}{c}\text { Specimen } \\
\text { orientation }\end{array}$ & Group & $\begin{array}{r}\text { Principal } \\
\text { slip system }\end{array}$ & $\begin{array}{c}\text { Combination for } \\
\text { C-L barrier }\end{array}$ & $\tau$ & $\varepsilon_{i j}$ & $r$ value \\
\hline A & $\mathrm{T}$ & $\begin{array}{l}\text { 1. (111) }[\overline{101}] \\
\text { 2. }(111)[110] \\
\text { 3. }(\overline{1} 11)[101] \\
\text { 4. }(\overline{111})[110]\end{array}$ & 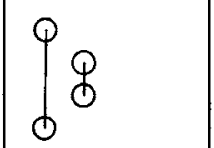 & $\frac{1}{\sqrt{6}}\left(\sigma_{22}-\sigma_{33}\right)$ & $\begin{array}{l}\varepsilon_{22}=g_{t} / \sqrt{6} \\
\varepsilon_{11}=0, \varepsilon_{33}=-\varepsilon_{22}\end{array}$ & 0 \\
\hline B & $\mathrm{T}$ & \begin{tabular}{l} 
1. (111) $[\overline{101}]$ \\
2. $(111)[101]$ \\
3. (111) $[101]$ \\
4. (111) $[\overline{1} 01]$ \\
\hdashline$-(111)[0 \overline{1} 1]$ \\
5. (11) \\
6. (111) $[011]$ \\
7. (111) $[011]$ \\
8. (111) $[011]$
\end{tabular} & $\int_{0}^{Q} \phi$ & $\begin{array}{l}\frac{1}{\sqrt{6}}\left(\sigma_{22}-\sigma_{33}\right) \\
\frac{1}{\sqrt{6}}\left(\sigma_{22}-\sigma_{11}\right)\end{array}$ & $\begin{array}{l}\varepsilon_{22}=g_{t} / \sqrt{6} \\
\varepsilon_{11}=0, \varepsilon_{33}=-\varepsilon_{22} \\
\varepsilon_{22}=g_{1} / \sqrt{6} \\
\varepsilon_{11}=-\varepsilon_{22}, \varepsilon_{33}=0\end{array}$ & \}$_{0}^{0} \begin{array}{l}1 \\
\text { extrinsic }\end{array}$ \\
\hline C & $\begin{array}{c}\mathrm{T} \\
---\end{array}$ & 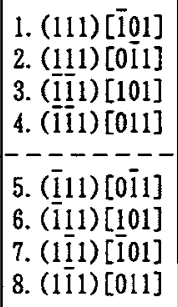 & $\oint_{\infty}^{Q} \phi$ & $\begin{array}{l}\frac{1}{\sqrt{6}}\left(\sigma_{22}-\sigma_{33}\right) \\
\frac{1}{\sqrt{6}}\left(\sigma_{22}-\sigma_{11}\right)\end{array}$ & $\begin{array}{l}\varepsilon_{22}=g_{t} / \sqrt{6} \\
\varepsilon_{11}=0, \varepsilon_{33}=-\varepsilon_{22} \\
\varepsilon_{22}=g_{n} / \sqrt{6} \\
\varepsilon_{11}=-\varepsilon_{22}, \varepsilon_{33}=0\end{array}$ & \}$_{\infty}^{0} \begin{array}{l}1 \\
\text { extrinsic }\end{array}$ \\
\hline $\mathrm{D}$ & W & $\begin{array}{l}\text { 1. (111) }[101] \\
\text { 2. (111) }[110] \\
\text { 3. }(111)[101] \\
\text { 4. (111) }[110]\end{array}$ & $\Phi$ & $\frac{1}{\sqrt{6}}\left(\sigma_{22}-\sigma_{11}\right)$ & $\begin{array}{l}\varepsilon_{22}=g_{w} / \sqrt{6} \\
\varepsilon_{11}=-\varepsilon_{22}, \varepsilon_{33}=0\end{array}$ & $\infty$ \\
\hline
\end{tabular}

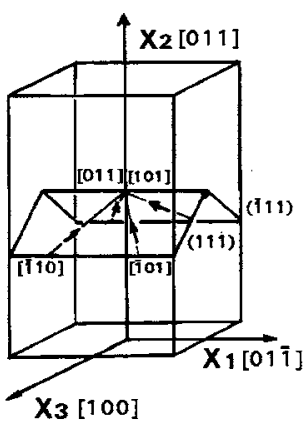

(a) Orientation A

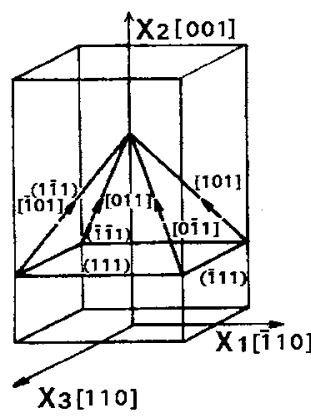

(c) Orientation C

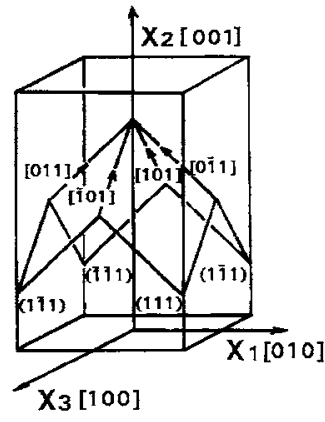

(b) Orientation B

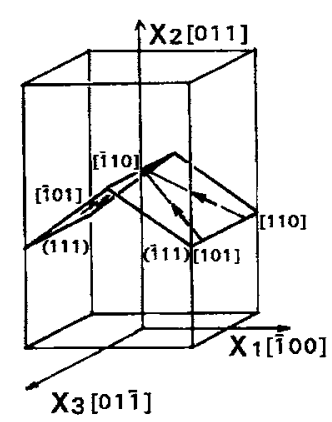

(d) Orientation D

Fig. 3 Arrangement of $\{111\}\langle\overline{1} 01\rangle$ slip systems for four kinds of specimens.

しかし，Table 1 火示すようK，多軸応力下では，4つの主 すべり系汇作用する分解好九断応力は，残りの4つの主す ベり系に作用する分解せん断応力之異なる。的し $\sigma_{11}>\sigma_{33}$ ならば，Tグループに属する4つの主すべり系が優先的に 活動し，このグループは試験片の厚さの及を減少させる。こ のグループに起因する塑性異方性は $\mathrm{A}$ 方位の塑性異方性と 同じである．もし $\sigma_{11}<\sigma_{33}$ ならば，W グループに属する 4 つの主すべり系が優先的に活動し, 試験片の幅のみを減少さ せる。 このグループに起因する塑性異方性は D 方位と同じ である。したがって，B方位の $r$ 值は応力状態に応じて 0 心まで変化する，一方，B方位をるつ薄板切欠き材比物いて は，Tグルーブに属するすべり系が切欠き周辺部による拘 束を汪とんど受けないため，切欠き引張強さは低いで西万ら。

C 方位:

$\mathrm{B}$ 方位の板を $X_{2}$ 軸のまわりに $45^{\circ}$ 回転すると C 方位の板 になる。C方位の塑性異方性は B 方位と同様に応力状態に 応じて0からの恋化する。しかし，両方位は，後汇述 ベるように，Lomer-Cottrell 障壁形成の点で異なっている.

\section{D 方位:}

$\mathrm{A}$ 方位の結晶を $X_{2}$ 軸のまわりに $90^{\circ}$ 回転すると D 方位の 結晶が得られる。この方位の 4 つの主すべり系は板幅のみ

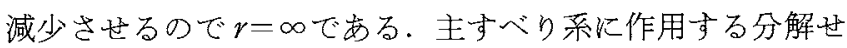


ん断応力は幅方向の応力 $\sigma_{11}$ のみの影響を受けるので，切欠 き引張強さは高いであろう。

\section{(2) Lomer-Cottrell 障壁の形成}

4 種類の方位に扣いて Lomer-Cottrell 障壁を形成するす ベり系の組み合わ度 Table 1 に示す。活動するすべり系の 間で Lomer-Cottrell 障壁を形成する場合，ひずみ硬化を促 し，強度を高めると考光られる。

\section{(3) すべり系の安定性}

引張軸方位が[011]方位である A, D 方位においては，ひ とつあるいは2つのすべり系のみが優先的にすべり，不安 定すべりを起こす可能性がある。しかし，引張軸方位が [001]万位である B，C方位では，不安定すべりは起こりに くいと考完られる。

\section{2. $\{010\}<101\rangle$ 型すべり系が活動するときの塑性異方性}

Fig. 4 KA，D 万位試験片の結晶力位とすべり系との幾何 学的関係を示与。なお，B，C方位に执いては，\{010\}面上で の分解孔九断応力が 0 になるため省略した。

A 方位 $(r=\infty)$ :

Table 2 飞示尗ように，せん断応力 $\tau$ は板嬮方向の応力 $\sigma_{11}$ の影響を受けるので，切欠き周辺部による拘束のため， 4つのすべり系は活動しにくい.

$\mathrm{D}$ 万位 $(r=0)$ :

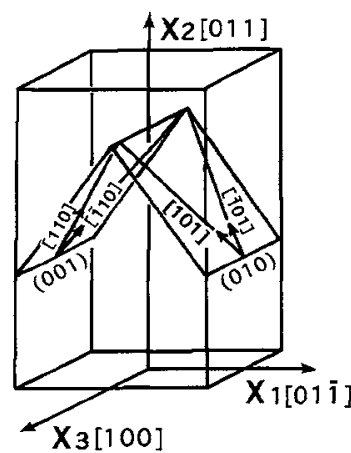

(a) Orientation A

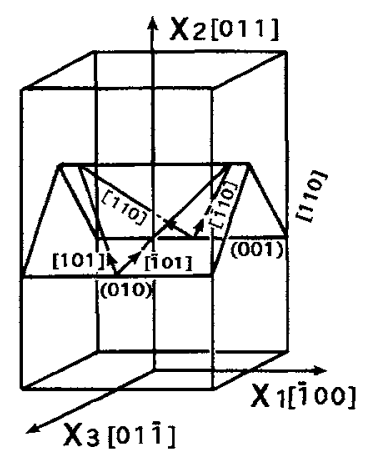

(b) Orientation $\mathrm{D}$

Fig. 4 Arrangement of $\{010\}\langle 101\rangle$ slip systems for two kinds of specimens.
薄板材では，両切欠きを結ぶ線上で $\sigma_{33} \fallingdotseq 0$ なので切欠き 拘束がない，また，すべての\{111\}〈101〉型すべり系(Fig. 3(d))が拘束されるため，このすべり系が活動する可能性が ある。

\section{III. 実 験 方 法}

Table 3 亿示す化学成分をすつ $\mathrm{Ni}$ 基超合金高純度 $\mathrm{Ar}$ 雲团気中で溶解し，ブリッジマン法により単結晶化した。方 位解析ののb，平滑引張試験片 (平行部寸法 $3.0 \times 2.8 \times 18.5$ $\mathrm{mm}^{3}$ ) 执よび第章で述べた 4 種類の方位関係をるつ切欠き 薄板引張試験片 (Fig. 5)をワイヤカット放電加工機を用いて 切り出した。試験片切り出し後, $1255^{\circ} \mathrm{C} て ゙ 10 \mathrm{~h}$ の溶体化熱

Table 3 Chemical composition (mass\%).

\begin{tabular}{cccccccccc}
\hline $\mathrm{Cr}$ & $\mathrm{Mo}$ & $\mathrm{Co}$ & $\mathrm{W}$ & $\mathrm{Ta}$ & $\mathrm{Ti}$ & $\mathrm{Al}$ & $\mathrm{Si}$ & $\mathrm{V}$ & $\mathrm{Ni}$ \\
\hline 10.11 & 2.50 & 9.97 & 0.04 & 0.07 & 4.75 & 5.73 & $>0.01$ & 0.93 & Bal.
\end{tabular}

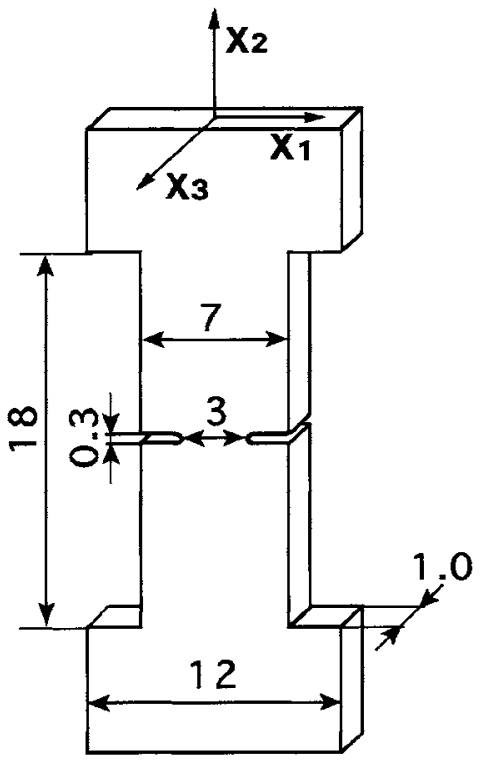

Fig. 5 Notched specimen $(\mathrm{mm})$.

Table 2 Resolved shear stress on each slip system $\tau$, plastic distortion $\varepsilon_{i j}$, and Lankford's $r$ value. $g_{\mathrm{t}}$ and $g_{\mathrm{w}}$ are the total distortion of the T- and W-Group slip systems, respectively.

\begin{tabular}{|c|c|c|c|c|c|}
\hline $\begin{array}{l}\text { Specimen } \\
\text { orientation }\end{array}$ & Group & $\begin{array}{l}\text { Principal } \\
\text { slip system }\end{array}$ & $\tau$ & $\varepsilon_{i j}$ & $r$ value \\
\hline $\mathrm{A}$ & W & $\begin{array}{ll}1 . & (010)[101] \\
2 . & (010)[101] \\
3 . & (001)[\overline{110}] \\
4 . & (001)[110]\end{array}$ & $\frac{\sqrt{2}}{4}\left(\sigma_{22}-\sigma_{11}\right)$ & $\begin{array}{l}\varepsilon_{22}=(\sqrt{2} / 4) g_{\mathrm{w}} \\
\varepsilon_{11}=-(\sqrt{2} / 4) g_{\mathrm{w}}, \varepsilon_{33}=0\end{array}$ & $\infty$ \\
\hline $\mathrm{D}$ & $\mathrm{T}$ & $\begin{array}{ll}\text { 1. } & (010)[101] \\
2 . & (001)[110] \\
3 . & (010)[\overline{101}] \\
4 . & (001)[\overline{110}]\end{array}$ & $\frac{\sqrt{2}}{4}\left(\sigma_{22}-\sigma_{33}\right)$ & $\begin{array}{l}\varepsilon_{22}=(\sqrt{2} / 4) g_{\mathrm{t}} \\
\varepsilon_{11}=0, \varepsilon_{33}=-(\sqrt{2} / 4) g_{\mathrm{t}}\end{array}$ & 0 \\
\hline
\end{tabular}


処理とそれに続いて $1100^{\circ} \mathrm{C}-10 \mathrm{~h}$ 空冷 $+850^{\circ} \mathrm{C}-20 \mathrm{~h}$ 空冷の時 効熱処理を施した。熱処理後の試料では，立方体形状の $y^{\prime}$ 粒子が規則正しく配列し，平均粒子径は $0.39 \mu \mathrm{m}$ ，体積率は $60 \%$ あった。熱処理終了後, 切欠き底半径 $0.15 \mathrm{~mm}$ の切 欠きを入れた。引張試験における引張速度は，平滑試験片で は $0.5 \mathrm{~mm} / \mathrm{min}\left(4.5 \times 10^{-4} \mathrm{~s}^{-1}\right)$, 切欠き試験片では 0.05 $\mathrm{mm} / \mathrm{min}$ で行った。クリープ試験は，平滑試験片では平行 部断面積に対し，また，切欠き試験片では切欠き底の有効断 面積に対して，応力 $350 \mathrm{MPa}$ を負荷した。試験は, $900^{\circ} \mathrm{C}$ で行った。

\section{N. 実験結果および考察}

\section{1.引張強度に及ぼす塑性異方性の影響}

切欠さ引張強さおよび切欠きクリープ特性に影響を及ぼす 因子としては，切欠きに起因する塑性拘束効果がまず考㝋ら

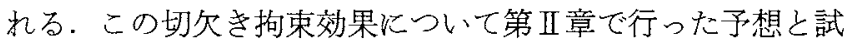
験結果を対照して検討する。

Miner 5 (7) は, René N-4 単結晶合金の引張試験に蛙いて， 室温から $980^{\circ} \mathrm{C}$ 広い温度範囲で，\{111\}<而1 型导べり系が 活動することを報告している。このすべり系の活動を仮定し て(Fig. 3)，本研究の $900^{\circ} \mathrm{C}$ に和壮る結果について考えてみ る，応力軸方位が[001]和よび[011]方位にある場合，\{111\} 〈101〉型すべり系に対するシュミット因子は0.4714であり， Fig. 3 中の $\{111\}\langle\overline{1} 01\rangle$ ずベ系に対するせん断応力は，平 滑材の場合，すべて等価となる，平滑引張試験片の応力-ひ ずみ曲線をFig.6(a) に示す。また，切欠き引張試験片の公 称応力-伸び線をFig. 6(b) 飞示す．平滑材に抽いては，平行 部が一様に変形するので公称ひずみを用いたが，切欠き村の 場合変形する部分が特定できないため，横軸に伸びを示し た。平滑材 (Fig. 6(a))では，[001]方位の方が[011]方位に 比べ，降伏強度拉よび引張強度と高い，切欠き材の引張強 度について比較すると(Fig. 7)，引張方向が[011]であるA 和よび D 万位より，引張方向が[001]である B 方位持よび C方位の方が若干高い。これは，[001]方位の引張強度が [011]方位より高いことに起因しているものと考えられる．

$\mathrm{A}$ 方位 $(r=\infty)$ では，切欠き強さが最小であった．A方位 に括いては，主すべり系の活動は板厚方向の応力 $\sigma_{33}$ の影響 のみを受けるが(Table 1)，薄板切欠き材に特いては， $\sigma_{33} \fallingdotseq$ 0 であるため，主すべり系の活動は切欠きの存在による拘束 を㭱とんど受けない，A方位の切欠き強さが最小となった ことに対する主たる原因はこの点にある. D位の場合， II.1.(1)節で述べたように，主すべり系は面内すべりを起こ 乙，板幅を收縮させるが，これが切欠き周辺部によって拘束 されて板幅方向の高い引張応力 $\sigma_{11}$ が発生する. その結果, 主すべり系を活動させるためには引張方向の高い引張応力 $\sigma_{22}$ が必要になる。これがD方位の切欠き強さが $\mathrm{A}$ 万位よ り高かった主たる原因である。

D 方位は，すべての\{111\}〈̄01〉型すべり系の活動が切欠
き周辺部により拘束されるため最も強いはずであるが，実際 の D 方位の引張強度は $\mathrm{C}$ 方位および $\mathrm{B}$ 方位よりも低い，D 方位では，Fig. 8 に示すように $\{010\}$ 面に沿った破面が観察 された：L1 $1_{2}$ 型金属間化合物では高温で $\{010\}\langle 101\rangle$ 型すべ り系(Fig. 4)が活動すると考兄られている(8)(9)。この金属間
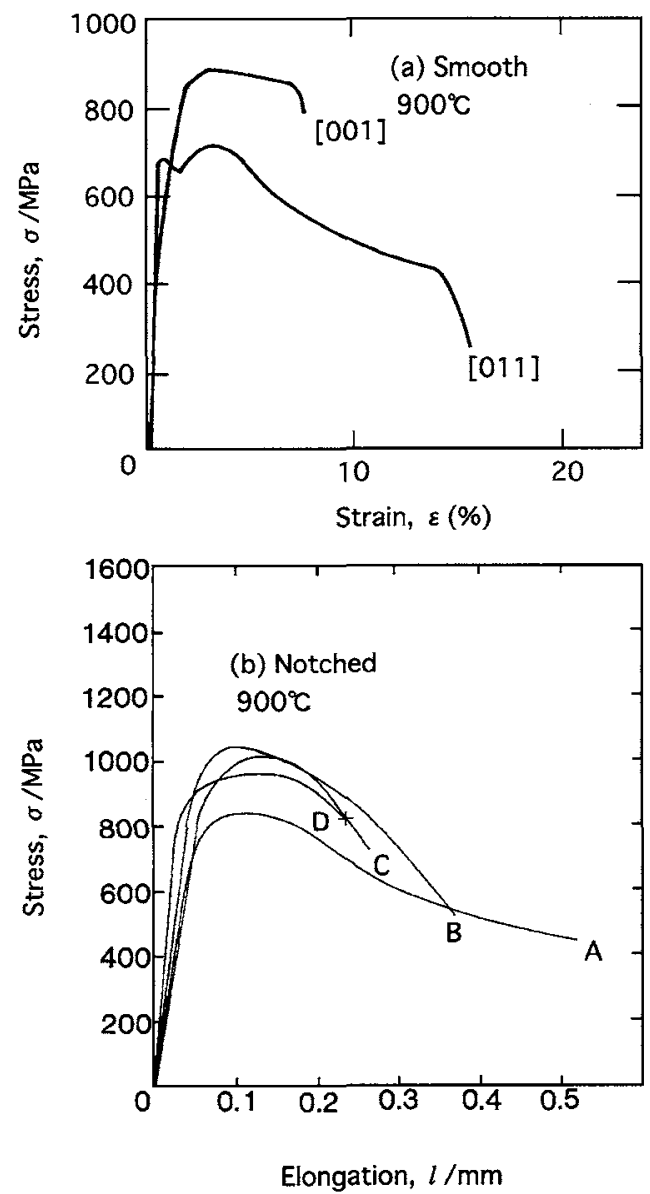

Fig. 6 Stress strain curves of (a) the smooth and (b) the notched specimens. Tensile tests were carried out in air with a strain rate of $4.5 \times 10^{-4} \mathrm{~s}^{-1}$ for the smooth specimens, and with a crosshead speed of $0.05 \mathrm{~mm} / \mathrm{min}$ for the notched specimens.

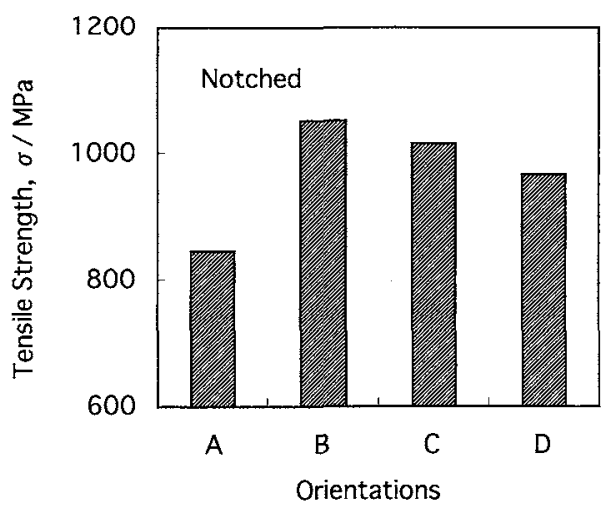

Fig. 7 Comparison of tensile strength of four kinds of the notched specimens. 

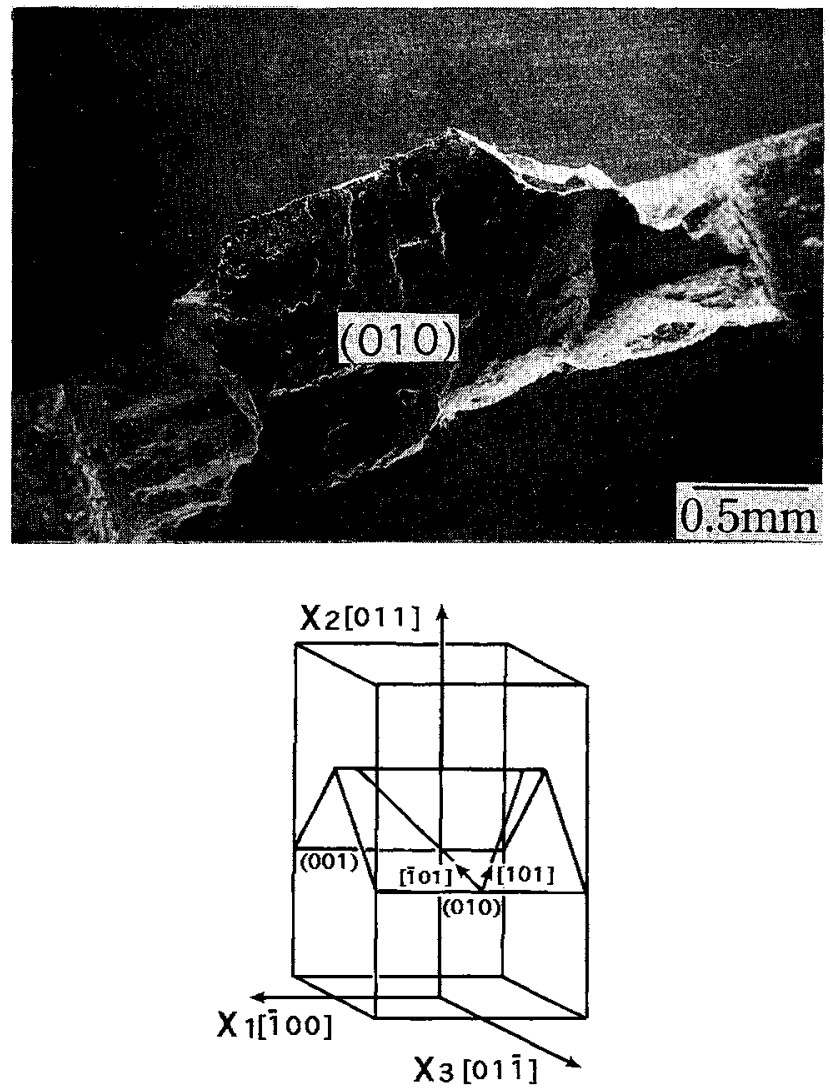

Fig. 8 Fracture surface of the D-orientation specimen which showed the cube slip plane macroscopically.

化合物を強化相とする $\mathrm{Ni}$ 基超合金単結晶でも，このすべり 系が高温域で活動することが十分考光られる(10)(11)。したが って，D方位では\{111\}面をすべり面とするすべり系(Fig. 3）㤉欠き周辺部に上る拘束を受けるため活動好ず，拘束 を受けない $\{010\}\langle 101\rangle$ 型すべり系が活動したため強度が低 かったものと考元られる。

\section{2. クリープ強度に及ぼす塑性異方性の影響}

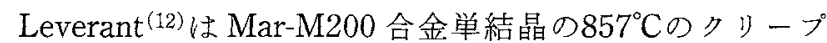
に括いて $\{111\} 〈 101\rangle$ 型すべり系が活動することを示唆して いることから，本研究の $900^{\circ} \mathrm{C}$ に和ける結果に乱いても， $\{111\}\langle\overline{1} 01\rangle$ 型すべり系(Fig. 3)の活動を仮定して考察する.

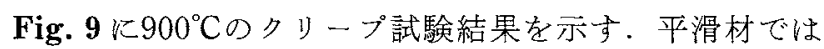
(Fig. 9(a))，[001]，[011]万位とも破断寿命はほ添同じであ ったが，破断ひずみは[001]万位の方が著しく大きい，次 に，切欠き材について検討してみると(Fig. 9(b))，C方位 が他方位に比較して優れた切欠きクリープ特性を示した。す なわわ，C方位の破断時間は最も長く，破断伸びは大きい。 D方位はC方位に次ぐ性質を示した。 A B B 方位の破断時間 は短く，破断伸びは小さい，平滑材では[001]方位の力が 3 倍以上る破断ひずみが大きいのに対して，切欠き材では，引 張軸方位が[011]方位である D 方位の破断伸びが，[001]方
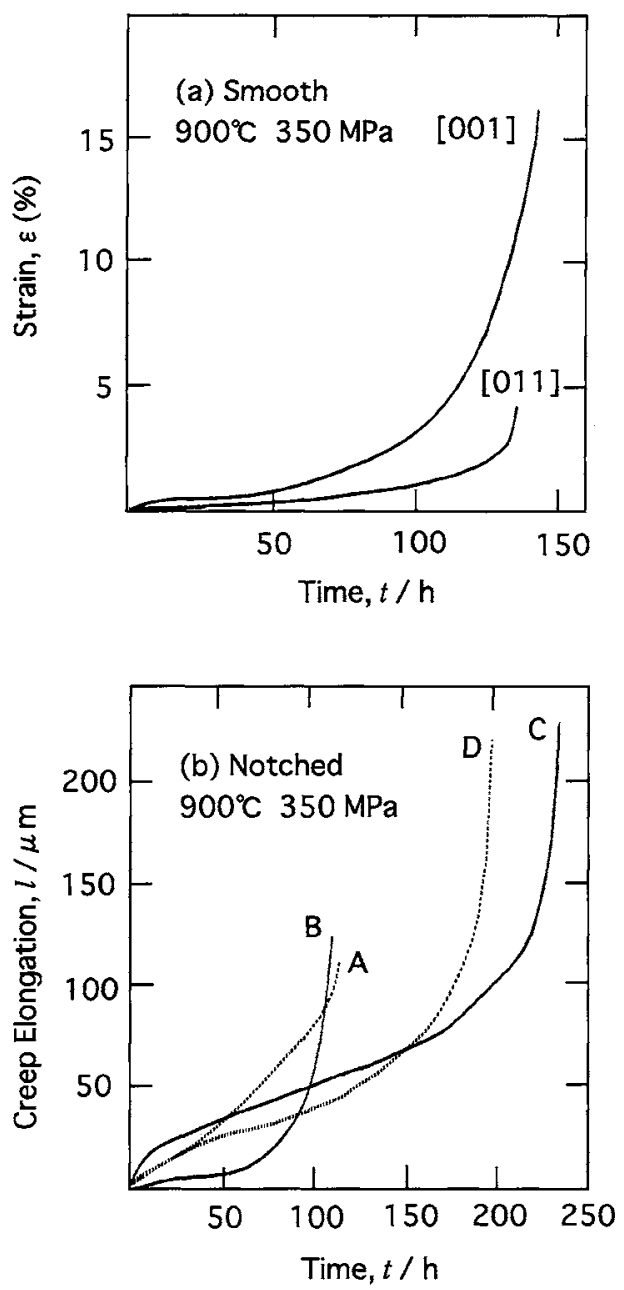

Fig. 9 Creep curves of (a) the smooth and (b) the notched specimens. Creep rupture tests were carried out under a nominal stress of $350 \mathrm{MPa}$ for the smooth specimens. In the case of the notched specimens, the stress was equally applied for the initial net cross-sectional area.

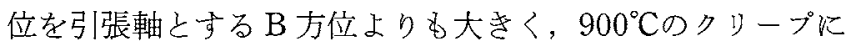
和いても応力軸方位だけでなく板厚方向の結晶方位の影響を 受けることは明らかである。

引張方位が $[001]$ 方位にある場合を考完てみる。C方位の 破断時間と破断伸びが B 方位の約 2 倍であった. B 方位と $\mathrm{C}$ 方位で性，薄板切欠き材では $\sigma_{33} \fallingdotseq 0$ であるため プに属するすべり系は涪之んど拘束を受けず優先的に活動 し，このグループは試験片の厚さのみを減少させる。乙か し，C方位の方が B 方位に比べ，破断寿命执よび破断伸び ともに大さい。れは，Table 1 に示したように，C方位に おいては拘束を受けないすべり系（Tグループのすべり系） の間で Lomer-Cottrell 障壁が形成されるのに対し，B方位 に掠いては形成されないためであると考党られる。

引張方向が同じ[011]方位である A 方位とD方位を比心゙

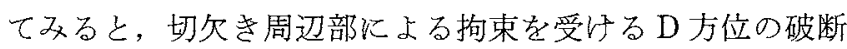
時間と破断伸びとも $\mathrm{A}$ 方位の約 2 倍近くなっている. D 方 
位の場合，前節(N.1.)で述べたように，主すべり系は面内 すべりを起こし板幅を収縮させるが，これが切欠き周辺部に よって拘束されて板幅方向の高い引張応力 $\sigma_{11}$ が発生する. その結果，主すべり系を活動させるためには引張方向の高い 応力 $\sigma_{22}$ が必要になる。これが D方位のクリーブ寿命が $\mathrm{A}$ 方位上り長かったことに対する主たる原因である。そして， 破断伸びが最小となった A 方位では，両切欠きを結ぶ狭い 領域に変形が局所化され，板厚が著しく減少することが考兄 られる。これらの実験結果は，\{111\}〈101〉型すべり系の活 動を仮定した結果と添添一致している。しかしながら，この すべり系の活動が切欠き周辺部によって拘束される D 方位 では，クリープ変形抵抗が最も高いはずであるが，Fig. 9(b)飞示すように，C方位と比べて寿命は短い。これは，

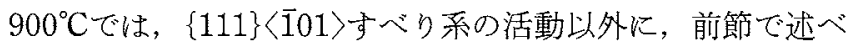
た $\{010\}\langle 101\rangle$ 型すべり系の活動，叔よび $\gamma$ 一界面に和ける 転位の上昇運動(13)(14)などの拡散支配の变形メカニズムが強 度に影響しているためと考光られる。

\section{V. 結言}

$\mathrm{Ni}$ 基超合金単結晶の平滑叔よび薄板切欠さ試験片を用い

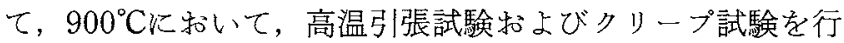
った，切欠き引張強さ拉よび切欠きクリープ強さと破断延性 は，単に引張方向の結晶方位に依存するだけでなく板厚方向 の結晶方位にも強く依存することが明らかになった．実験結 果は，\{111\}〈101〉型すべり系の活動老仮定すると经注説明 できた。しかしながら，このすべり系の活動が切欠き周辺部
によって拘束される D 方位は最も強度が高いはずであるが， いずれの試験でも，C方位の方が強度が高かった。これは，

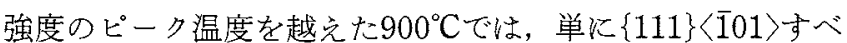
り以外飞，\{010\}〈101〉すべり蛒よび拡散支配の变形メカ二 ズムが強度に影響するためで每る。

\section{文献}

(1) K. Sugimoto, T. Sakaki, T. Horie, K. Kuramoto and O. Miyagawa: Metall. Trans. A, 16A(1985), 1457

（2）吸木庸晃，杉本公一，宮川大海：日本機械学会論文集 $A$, 48(1982), 1332 .

(3) T. Sakaki, K. Kakehi, T. Adachi and T. Tanaka: Creep and Fracture of Engineering Materials and Structures, Ed. by B. Wilshire and R. W. Evans, The Institute of Metals, London, (1990), 313

(4) K. Kakehi, T. Sakaki, J. M. Gui and Y. Misaki: Creep and Fracture of Engineering Materials and Structures, Ed. by B. Wilshire and R. W. Evans, The Institute of Materials, London, (1993), 221.

（5）筧 幸次, 坂木庸晃, 新谷晋由: 高温に批る力学的挙動(日 本金属学会シソポジウム予稿集)，(1992), 19.

(6) G. T. Hahn and A. R. Rosenfield: Acta Metall., 13(1965), 293.

(7) R. V. Miner, T. P. Gabb, J. Gayda and K. J. Hemker: Metall. Trans. A, 17A (1986) 491

(8) S. M. Copley and B. H. Kear: Trans. TMS-AIME, 239(1967), 977

(9) A. E. Staton-Bevan and R. D. Rawlings: Philos. Mag., $32(1975), 787$

(10) R. Völkl, U. Glatzel and M. Feller-Kniepmeier: Scripta Metall. Mater., 31 (1994), 1481.

(11) G. E. Bobeck and R. V. Miner: Metall. Trans. A, 19A (1988), 2733.

(12) G. R. Leverant, B. H. Kear and J. M. Oblak: Metall. Trans., 4(1973), 355.

(13) C. Carry and J. L. Strudel: Acta Metall., 25(1977), 767.

(14) C. Carry and J. L. Strudel: Acta Metall., 26(1978), 859. 